\title{
Biosynthesis of Glycoprotein-Glycosyl Transferases during the Cell Cycle
}

\author{
YoshITAKA AOI \\ The Institute of Medical Science, The University of Tokyo, \\ Minato-ku, Tokyo 108
}

Aor, Y. Biosynthesis of Glycoprotein-Glycosyl Transferases during the Cell Cycle. Tohoku J. exp. Med., 1978, 124 (2), 139-144 - The levels of glycoprotein-glycosyl transferases increased at the late $G_{1}$-early $\mathbf{S}$ phase during the cell cycle both in the plasma membrane and in the microsomal fraction. The levels of the enzymes showed a "peak pattern" during the cell cycle. Elevation of the enzyme activity at earlier stages was not influenced by cytosine arabinoside but that at late $G_{1}$ was completely inhibited. ___ glycoprotein; glycoproteinglycosyl transferase; cell cycle

Interest in the plasma membrane as an organelle involved in the regulation of cell-cell interactions and cell duplication has been heightened by the demonstration that surface components are specifically altered as a result of viral transformation and that the cell surface may give rise to factors which promote cell growth (Tooze 1973).

To clarify the role of plasma membrane in the regulation of cell growth, several approaches have been utilized, one of these being to describe how membrane proteins change as a function of the multiplicative cell cycle. When cells in the $G_{0}$ or resting state are stimulated to resume the growth cycle, there is generally an alteration in surface structures as demonstrated on the basis of at least four biological phenomena. The first is concerned with the appearance or disappearance of antigenicity (Cikes and Friberg 1971). The second deals with the binding sites for lectins and viruses (Glick and Buck 1973), the third, with chemical groups identified by charge or by direct measurement (Malenkov et al. 1972) and the fourth, with transport mechanisms (Sander and Pardee 1972).

It seems clear that the cell cycle variations observed with respect to any of the above noted functions may result from movement of molecules through a fluid membrane and not necessarily from the de novo biosynthesis of membrane components. It is important to study as directly as possible the biosynthesis of molecules at the cell membrane. Such an approach has been adopted by a number of laboratories (Onodera and Sheinin 1970; Nowakowski et al. 1972).

The studies described herein were designed to follow the de novo biosynthesis of glycoprotein-glycosyl transferases during the cell cycle. I was particularly interested in glycoprotein-glycosyl transferases as membrane components for the

Received for publication, June 8, 1977. 
following reasons. First, this enzyme system is involved in the biosynthesis of glycoproteins that are major constitutents of plasma membrane and one of them has been reported to be a glycoprotein itself (Podolsky et al. 1974). Secondly, the glycosyl transferases are localized both in the plasma membrane and in the Golgi membrane. The fusion of Golgi membrane with the plasma membrane has been reported as a process of surface membrane formation in certain cases (Bennet et al. 1974). Thirdly, the activity of one of these enzymes, sialyl transferase was considerably altered in a temperature-sensitive mutant of simian virus 40 transformed cells (Onodera et al. 1976).

The biosynthesis of glycoprotein-glycosyl transferases of the cell surface and inner membrane, presumably derived from Golgi membrane, occurred at late $\mathrm{G}_{1^{-}}$ early $\mathrm{S}$ phase during the cell cycle.

\section{Materials and Methods}

C3H-2K-C4 cells established from the kidney of a new born $\mathrm{C} 3 \mathrm{H} / \mathrm{He}$ mouse by Yoshikura and his associates (1967) were used throughout the experiments. The cells were grown at $37^{\circ} \mathrm{C}$ in Eagle's minimal essential medium supplemented with $10 \%$ calf serum.

Cells were grown until a monolayer formed and were left 4-5 days. All the cells were arrested at $G_{0}$ or $G_{1}$ stage of the cell cycle and cells divided only once in a synchronized fashion upon renewal of cultural medium supplemented with $10 \%$ calf serum. This method, which does not use trypsin or EDTA for the new culture, eliminates the possibility that the regeneration of some membrane components may occur due to damage of the cell surface by trypsinization and permits the author to investigate more precisely the period of the cell cycle at which individual components are synthesized.

At various intervals after synchronization, cells were harvested by scraping off the monolayer (without the use of trypsin-EDTA) and were centrifuged at $1000 \times \mathrm{G}$ for $5 \mathrm{~min}$. After centrifugation, the cells were pulse-labeled for $1 \mathrm{hr}$ at $37^{\circ} \mathrm{C}$ with $10 \mu \mathrm{Ci} / \mathrm{ml}\left[{ }^{3} \mathrm{H}\right]-\mathrm{TdR}$ $(15.2 \mathrm{Ci} / \mathrm{mmole})$ in Eagle's medium. The incorporation of thymidine into the $10 \%$ cold trichloroacetic acid precipitable fraction was determined using a Beckman scintillation counter and was expressed as c.p.m. per $10^{5}$ cells per hr. Cell numbers were determined in a Coulter counter and cell viability was checked with the trypan blue dye exclusion test.

Desialized fetuin for sialyl transferase and desialized-degalactosized fetuin for galactosyl transferase were prepared according to Grimes' method (1970). Pancreatic RNase was used as the acceptor for $\mathrm{N}$-acetylglucosaminyl transferase.

Protein determination was carried out according to the method of Lowry et al. (1951).

UDP-[ $\left.{ }^{3} \mathrm{H}\right]$-galactose $(1.24 \mathrm{Ci} / \mathrm{mmole}), \mathrm{CMP}-\left[{ }^{14} \mathrm{C}\right]$-sialic acid $(265 \mathrm{mCi} / \mathrm{mmole})$, GDP-[ $\left.{ }^{14} \mathrm{C}\right]$ fucose (170 mCi/mmole), UDP-[ $\left[{ }^{4} \mathrm{C}\right]-\mathrm{N}$-acetylglucosamine $(257 \mathrm{mCi} / \mathrm{mmole})$ were obtained from New England Nuclear. Fetuin was purchased from Grand Island Biological Co. Cytosine arabinoside and pancreatic ribonuclease were purchased from Sigma Chem. Co., St Louis, Mo.

In order to inhibit protein biosynthesis, the cells were incubated with medium containing $10 \mu \mathrm{g} / \mathrm{ml}$ of cytosine arabinoside after release from the $G_{0}$ or $G_{1}$ phase. The effect of the drug on the level of enzyme activity was examined at various intervals.

The plasma membrane and the microsomal fraction from $\mathrm{C} 3 \mathrm{H}-2 \mathrm{~K}-\mathrm{C} 4$ cells were prepared according to the method of Brunette and Till (1971).

The glycoprotein-glycosyl transferase activity was measured by the method of Grimes (1970). Details are given in the legends accompanying Fig. 1. All enzyme assays were done in duplicate. The enzyme activity was expressed as c.p.m. per mg of protein per hr or c.p.m. per cell number per hr. 


\section{Results}

As shown in Fig. 1 (a), the cells entered $\mathrm{S}$ phase at $18 \mathrm{hr}$ and the mitotic cells were observed at $30 \mathrm{hr}$ after subculture. Cells progressed through one round of proliferation of the cell cycle and were arrested again in a quiescent state. This confirms Yoshikura's results (1967) and indicates that this system provides an ideal system for the study of biosynthesis of the cell membrane components in terms of cell division.

(a)

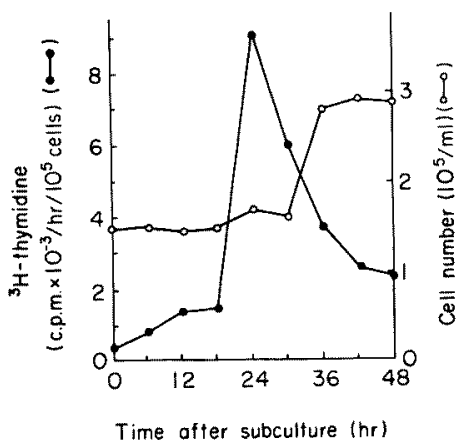

(b)

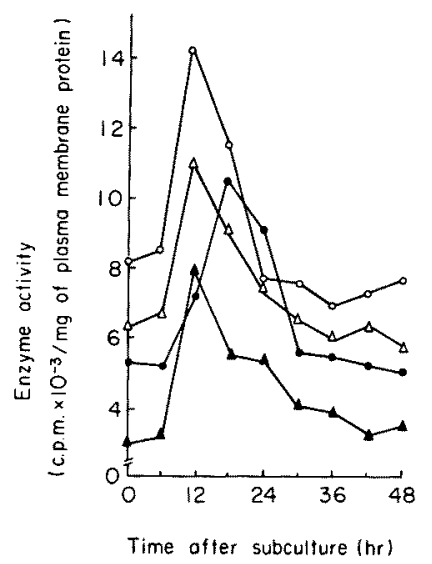

Fig. 1. Synchronization of $\mathrm{C} 3 \mathrm{H}-2 \mathrm{~K}-\mathrm{C} 4$ cells and the levels of glycoprotein-glycosyl transferase activities of the plasma membrane.

The complete enzyme system contained the following in a volume of $0.19 \mathrm{ml} ; 10 \mu \mathrm{l}$ of $0.1 \mathrm{M} \mathrm{MnCl}_{2}, 10 \mu \mathrm{l}$ of $0.1 \mathrm{M} \mathrm{MgCl}, 10 \mu \mathrm{l}$ of phosphate buffer saline ( $\mathrm{pH} 7.2$ ), $50 \mu \mathrm{l}$ of exogenous acceptor (450 $\mu \mathrm{g}$ of protein), $10 \mu \mathrm{l}$ of radioactive nucleotide sugar and $0.1 \mathrm{ml}$ of plasma membrane (100-150 $\mu \mathrm{g}$ of protein) or microsomal fraction (100-150 $\mu \mathrm{g}$ of protein). The reaction mxitures were incubated for $60 \mathrm{~min}$ at $35^{\circ} \mathrm{C}$ and then $0.5 \mathrm{ml}$ of cold $1 \%$ phosphotungstic acid in $0.5 \mathrm{~N} \mathrm{HCl}$ was added and the precipitable fraction was dissolved in ammonia water and the radioactivity was determined in a liquid scintillation counter. In (b):

$\circ-0$ sialyl transferase; $\bullet-$ galactosyl transferase; $\Delta-\Delta$ fucosyl transferase;

$\Lambda \mathrm{N}$-acetyl glucosaminyl transferase.

The levels of glycoprotein-glycosyl transferases were estimated in the various fractions during the cell cycle. First, the levels of those enzymes of the plasma membrane were examined at regular intervals during the cell cycle. Only the transfer of various sugars from nucleotide sugars to the exogenous acceptors were measured. Sialyl, fucosyl and $\mathrm{N}$-acetylglucosaminyl transferases showed the highest activities at $12 \mathrm{hr}$ after subculture and the levels declined as the cells entered $\mathrm{S}$ phase and progressed through $\mathrm{G}_{2}$ phase. The levels at mitosis were the same as those in the quiescent state. Galactosyl transferase was highest at $18 \mathrm{hr}$, slightly later than the others, and the enzyme activity decreased as the cells went through $\mathrm{S}$ and $\mathrm{G}_{2}$ phase. All the four glycoprotein-glycosyl transferases were expressed on the cell surface at the late $G_{1}$-early $S$ phase of the cell cycle (Fig. $1(b)$ ). 
TABLE 1. Inhibitory effect of cytosine arabinoside on sialyl transferase activity during the cell cycle

\begin{tabular}{|c|c|c|c|c|}
\hline \multirow[b]{2}{*}{ Time } & \multicolumn{2}{|c|}{ Plasma membrane } & \multicolumn{2}{|c|}{ Microsomal fraction } \\
\hline & $\begin{array}{l}\text { Without cytosine } \\
\text { arabinoside }\end{array}$ & $\begin{array}{l}\text { With cytosine } \\
\text { arabinoside }\end{array}$ & $\begin{array}{l}\text { Without cytosine } \\
\text { arabinoside }\end{array}$ & $\begin{array}{l}\text { With cytosine } \\
\text { arabinoside }\end{array}$ \\
\hline $0 \mathrm{hr}$ & $4081 \pm 154^{*}(100) \dagger$ & $4017 \pm 129(100)$ & $10352 \pm 182(100)$ & $10768 \pm 207(100)$ \\
\hline 6 & $4367 \pm 169(107)$ & $4740 \pm 203(118)$ & $12526 \pm 221(121)$ & $13890 \pm 276(129)$ \\
\hline 12 & $7142 \pm 130(175)$ & $4218 \pm 159(105)$ & $15212 \pm 198(147)$ & $10230 \pm 177(95)$ \\
\hline 24 & $3795 \pm 94(93)$ & $3132 \pm 201(78)$ & $12319 \pm 300(119)$ & $8722 \pm 214(81)$ \\
\hline
\end{tabular}

* Specific activity: (exogenous-endogenous) c.p.m. \pm s.E./mg of protein per hr.

$\dagger$ Relative activity (\%).

However it is not clear whether or not the rapid decline of the enzyme activity was due to a rapid turnover or to a masking of the cell surface enzymes.

Since glycoprotein-glycosyl transferases are located both in the plasma membrane and in the inner membranes that are presumably derived from the smooth surface endoplasmic reticulum, or Golgi membrane, it was pertinent to ask whether or not the elevation of enzyme levels in both fractions were coincident.

To test whether the increase in these enzyme activities in each membrane fraction is due to de novo synthesis or to the organization of the preexisting enzyme molecules into the membrane, the effect of cytosine arabinoside on the increase of enzyme activity was exmained. The drug $(10 \mu \mathrm{g} / \mathrm{ml})$ was added when the fresh medium was supplied to stimulate cells to go through one round of proliferation, and the level of sialyl transferase with or without acceptor was measured during the cell cycle. Results are shown in Table 1. A few interesting facts were demonstrated. The level of sialyl transferase at $6 \mathrm{hr}$ was not influenced by the drug either at the plasma membrane or in the isolated microsomal fraction. The increases in enzyme activity at $12 \mathrm{hr}$ and $24 \mathrm{hr}$ were completely inhibited by the drug. This indicated that the increased activities at $12 \mathrm{hr}$ and $24 \mathrm{hr}$ were due to the de novo biosynthesis of glycoprotein-glycosyl transferase. It is not clear, however, whether the insensitivity of the enzyme level to the drug at an earlier phase, e.g., at $6 \mathrm{hr}$ after subculture, is due to the organization of the preexisting enzyme molecules or to topological alteration of the enzyme in the membrane structure, which exposes the enzymic catalytic site. The results indicate that de novo biosynthesis of glycoprotein-glycosyl transferase starts simultaneously at $12 \mathrm{hr}$ and that the levels of these enzymes decline very sharply at the $S$ or $G_{2}$ phase of the cell cycle.

\section{Discussion}

Several interesting results were obtained from the present investigation. First, the levels of the plasma membrane glycoprotein-glycosyl transferases were elevated at the late $\mathrm{G}_{1}$-early $\mathrm{S}$ phase. It can be considered that the elevated levels of the enzyme activities are due to changes in the cell surface topology 
during the cell cycle. Scanning electron microscopic observations have recently demonstrated that morphological alteration of the cell surface membrane occurred at $G_{1}$ phase with the appearance of microvilli on the cell surface. However, these are not dircet evidence suggesting any correlation between the appearance of the microvilli and glycosyl transferases. Therefore, to determine whether the elevated levels of the enzyme activities are due to the alteration of cell surface topology or not, the enzyme activities were measured both in the isolated plasma membrane and in the microsomal fraction. The elevated levels of glycoproteinglycosyl transferases in the isolated membrane and microsomal fraction were also observed at the late $G_{1}$-early $S$ phase during the cell cycle (data not shown). It is therefore unlikely that the elevated levels of the enzymes are due only to topological alteration of the cell surface. Furthermore the inhibition of protein biosynthesis with cytosine arabinoside resulting in the phenomena described above indicates that the increase at $12-18 \mathrm{hr}$ after subculture is due to de novo biosynthesis of the enzyme molecules.

On the other hand, the patterns of enzyme synthesis in the cell cycle can be classified into several groups according to Mitchison (1969), e.g., "step enzyme", "peak enzyme" and "linear enzyme". Most of the enzymes that have been examined are synthesized discontinuously at a particular stage of the cell cycle. If the enzyme is stable, the pattern is a "step". A "peak enzyme" is also synthesized at one point in the cell cycle, but it is unstable and the activity falls off because of inactivation or breakdown of the molecule. From the present results, the pattern of these enzymes is that of a "peak enzyme". These results confirmed those of Bosmann (1974), but the stage when de novo biosynthesis occurred was slightly different. In Bosmann's system, i.e., L5178Y mouse derived lymphoma cells, most of enzymes were synthesized at $\mathrm{S}$ phase. These differences may depend on the doubling times of the cell, the cultivation method, i.e., growth in suspension or on substratum, or the genotype of the cell, e.g., transformed or normal cell line.

Secondly, the increase of sialyl transferase activity at an earlier stage of the cell cycle, i.e., at $6 \mathrm{hr}$ after subculture, was not influenced by the drug. This indicated that the increase at this stage was not due to de novo biosynthesis but rather to the organization of the preexisting enzyme molecules and/or topological alteration of the cell surface membrane structures.

Many investigators have reported that the biosynthesis of glycoprotein occurs at $G_{1}$ stage and this is consistent with the present results of glycosyl transferases (Onodera and Sheinin 1970). Another complex carbohydrate, glycolipid, was synthesized at a different period of the cell cycle (M-early $G_{1}$ phae) (Chatterjee et al. 1973). It is interesting that the biosynthesis of two major complex carbohydrates in the membrane is strictly regulated in the cell cycle. These results prompted the author to investigate more closely how membrane proteins are synthesized during the cell cycle depending upon whether they are glycoproteins, i.e., proteins containing a suger moiety, or not. 


\section{Acknowledgment}

I would like to express thanks to Dr. K. Onodera for his helpful discussion.

\section{References}

1) Bennet, G., Leblond, C.P. \& Haddad, A (1974) Migration of glycoprotein from the Golgi apparatus to the surface of various cell types as shown by radioautography after labeled fucose injection into rats. J. Cell Biol., 60, 258-284.

2) Bosmann, H.B. (1974) Cell plasma membrane external surface glycosyltransferases: activity in the cell mitotic cycle. Biochim. biophys. Acta (Amst.), 339, 438-441.

3) Brunette, D.M. \& Till, J.E. (1971) A rapid method for the isolation of L-cell surface membranes using an aqueous two-phase polymer system. J. Membrane Biol., 5, 215224.

4) Chatterjee, S., Sweeley, C.C. \& Velicer, L.F. (1973) Biosynthesis of proteins, nucleic acids and glycosphingolipids by synchronized KB cells. Biochem. biophys. Res. Commun., 54, 585-592.

5) Cikes, M. \& Friberg, S., Jr. (1971) Expression of H-2 and moloney leukemia virusdetermined cell-surface antigens in synchronized cultures of a mouse cell line. Proc. nat. Acad. Sci. (Wash.), 68, 566-569.

6) Glick, M.C. \& Buck, C.A. (1973) Glycoproteins from the surface of metaphase cells. Biochemistry, 12, 85-90.

7) Grimes, W.J. (1970) Sialic acid transferases and sialic acid levels in normal and transformed cells. J. biol. Chem., 9, 5083-5091.

8) Lowry, O.H., Rosebrough, N.J., Farr, A.L. \& Randall, R.J. (1951) Protein measurement with the folin phenol reagent. J. biol. Chem., 193, 265-275.

9) Malenkov, A.G., Voeikov, V.L. \& Ovchinnikov, Y.A. (1972) Electroconductivity changes during the mitotic cycle in Ehrlich ascites tumor cells. Biochim. biophys. Acta (Amst.), 255, 304-310.

10) Mitchison, J.M. (1969) Enzyme synthesis in synchronous cultures. Science, 165, 657-663.

11) Nowakowski, M., Atkinson, P.H. \& Summers, D.F. (1972) Incorporation of fucose into Hera cell plasma membranes during the cell cycle. Biochim. biophys. Acta (Amst.), 266, 154-160.

12) Onodera, K. \& Sheinin, R. (1970) Macromolecular glycosamine containing components of the surface of cultivated mouse cells. J. Cell Sci., 7, 337-355.

13) Onodera, K., Yamaguchi, N., Kuchino, T. \& Aoi, Y. (1976) Alterations in surface glycoproteins and level of sialyl-transferase of cells transformed by a temperaturesensitive mutant of simian virus 40. Proc. nat. Acad. Sci. (Wash.), 73, 4090-4094.

14) Podolsky, D.K., Weiser, M.M., La Mont, J. \& Isselbacher, K.J. (1974) Galactosyltransferase and concanavalin A agglutination of cells. Proc. nat. Acad. Sci. (Wash.), 71, 904-908.

15) Sander, G. \& Pardee, A.B. (1972) Transport changes in synchronously growing CHO and L cells. J. Cell Physiol., 80, 267-275.

16) Tooze, J. (1973) The Molecular Biology of Tumor Viruses, edited by J. Tooze, Cold Spring Harbor Lab., Cold Spring Harbor, N.Y., pp. 173-268.

17) Yoshikura, H., Hirokawa, Y. \& Yamada, M. (1967) Synchronized cell division induced by medium change. Exp. Cell Res., 48, 226-228. 